\title{
ASPEK PERLINDUNGAN HUKUM BAGI PEWARALABA DIKAITKAN DENGAN PENEGAKAN HUKUM KONTRAK
}

\author{
oleh: \\ Rachmat Suharno
}

\begin{abstract}
ABSTRAK
Bisnis waralaba sebagai suatu sistem bisnis mempunyai karakteristik tersendiri di dalam kehidupan ekonomi dan juga menimbulkan permasalahan di bidang hukum dikarenakan bisnis waralaba ini didasarkan pada suatu perjanjian yang menimbulkan hak dan kewajiban para pihak, sehingga diperlukan adanya perlindungan hukum yang saling menguntungkan bagi masing-masing pihak. Penelitian ini menggunakan jenis penelitian kualitatif dengan menggunakan pendekatan penelitian normatif-yuridis. Penelitian yang dilakukan selain melakukan pengkajian terhadap peraturan perundang-undangan, buku-buku, dan jurnal (library research) yang berhubungan. Perlindungan waralaba memberikan dampak yang sangat significant terhadap penerima waralaba. Perlindungan atas kepentingan pihak penerima waralaba sangat diperlukan, karena pada kenyataanya pihak penerima waralaba selalu berada dalam pihak yang dirugikan., bahwa perlindungan hukum yang diberikan kepada penerima waralaba adalah berupa perjanjian waralaba yang dibuat oleh pemberi waralaba yang meliputi hak dan kewajiban penerima waralaba. Dalam perjanjian waralaba tersebut terdapat lebih banyaknya kewajiban yang harus ditanggung dibandingkan hak yang diperoleh penerima waralaba.Prosedur pendaftaran waralaba tidak menentukan sahnya suatu kontrak waralaba karena produsen tersebut hanya diatur melalui PP No. 42/2007 bukan melalui Undang-Undang. Sekalipun tidak menentukan syarat sahnya suatu perjanjian waralaba, prosedur mengenai pendaftaran waralaba tidak dapat dikesampingkan begitu saja. Dalam hal perjanjian waralaba dan prospektus penawaran waralaba tidak didaftarkan, maka terdapat sanksi yang dapat dijatuhkan sebagaimana dalam Pasal 16 ayat (1) Peraturan Pemerintah Nomor 42 Tahun 2007 tentang Waralaba. Sanksi yang diberikan dapat berupa sanksi administratif berupa peringatan tertulis dan sanksi administratif berupa denda.
\end{abstract}

Kata Kunci: Perlindungan Hukum, Perolehan Izin

\section{PENDAHULUAN}

Persaingan di dunia bisnis semakin hari semakin ketat. Hal ini menyadarkan para pengusaha untuk mencari pendekatan-pendekatan serta terobosan yang inovatif guna merebut pasarnya agar dapat terus bertahan,dan ekspansi atau pengembangan usaha menjadi pilihan wajib para pelaku usaha. Berhasil atau tidaknya ekspansi usaha sangat ditentukan oleh efektif atau tidaknya strategi pemasaran yang dilakukan.

Era globalisasi yang melanda di berbagai bidang, terutama dalam bidang perdagangan dan jasa. saat ini orang banyak yang memulai usahanya dengan cara membeli sistem bisnis atau yang dikenal dengan istilah "franchise".

Franchise masuk ke dalam tatanan hukum masyarakat Indonesia, istilah franchise selanjutnya menjadi istilah yang akrab dengan masyarakat bisnis Indonesia dan menarik perhatian banyak pihak untuk mendalaminya. Kemudian istilah franchise diistilahkan sebagai waralaba yang diperkenalkan oleh Lembaga Pendidikan dan Pengembangan Manajemen (LPPM). ${ }^{1}$ Waralaba berasal dari kata "wara" (lebih atau istimewa) dan "laba" (untung) sehingga waralaba berarti usaha yang memberikan laba lebih atau istimewa.

Istilah franchise berasal dari bahasa Perancis yang artinya bebas dari perintah (free

1

Barly Haliem, Mengembangkan Bisnis Tanpa Modal, Kontan, 7 April 2003, hlm. 7

Wacana Paramarta: Jurnal Ilmu Hukum, ISSN-p 1412-4793, ISSN-e 2684-7434 
from servitude) yang dalam bidang bisnis' berarti kebebasan yang diperoleh oleh seorang wirausahawan untuk menjalankan sendiri suatu usaha tertentu dalam wilayah tertentu. ${ }^{2}$

Pengertian waralaba dapat ditemukan pada Pasal 1 angka (1) PP RI No. 42/2007 tentang Waralaba mendefinisikan waralaba sebagai berikut:

"Waralaba adalah hak khusus yang dimiliki oleh orang perseorangan atau badan usaha terhadap sistem bisnis dengan ciri khas usaha dalam rangka memasarkan barang dan/atau jasa yang telah terbukti berhasil dan dapat dimanfaatkan dan/atau digunakan oleh pihak lain berdasarkan perjanjian waralaba."

Pelaksanaan teknis waralaba di Indonesia diatur oleh PP No.16/1997 tentang Waralaba dan Kepmen Perindustrian dan Perdagangan No. 259/MPP/Kep/7/1997 tentang Ketentuan dan Tata Cara Pelaksanaan Pendaftaran Usaha Waralaba.

Kehadiran bisnis waralaba sebagai suatu sistem bisnis mempunyai karakteristik tersendiri di dalam kehidupan ekonomi dan juga menimbulkan permasalahan di bidang hukum dikarenakan bisnis waralaba ini didasarkan pada suatu perjanjian yang menimbulkan hak dan kewajiban para pihak, sehingga diperlukan adanya perlindungan hukum yang saling menguntungkan bagi masing-masing pihak.

Perkembangan bisnis ini sudah seyogyanya diiringi dengan perlindungan hukum yang memadai agar tidak ada pihak yang dirugikan. Dalam PP No. 42/2007 tersebut juga menentukan bahwa waralaba dilaksanakan berdasarkan suatu kontrak waralaba yang harus didaftarkan pada instansi Pemerintah yang berwenang. Kontrak waralaba setidak-tidaknya juga akan mengatur mengenai izin untuk menggunakan merek dagang dan/atau jasa, dan izin untuk menerapkan sistem bisnis yang dilindungi sebagai rahasia dagang, milik pemberi waralaba oleh penerima waralaba. Namun, baik pemberi waralaba maupun penerima waralaba sebagai pihak-pihak dalam kontrak waralaba pada praktik di dunia bisnis di Indonesia hingga saat ini, masih sangat jarang yang mengajukan permohonan pencatatan dan pendaftaran kontrak waralabanya kepada instansi Pemerintah yang berwenang. Hal ini disebabkan karena adanya suatu persoalan hukum, yaitu aturan hukum di bidang waralaba yang kabur.

Berdasarkan uraian tersebut, permasalahan yang akan diteliti antara lain sebagai berikut :

1. Bagaimana perlindungan hukum dan upaya hukum bagi penerima waralaba terhadap klausul-klausul kontrak waralaba yang tidak seimbang dan bertentangan dengan hukum persaingan usaha yang dapat ditempuh jika terjadi wanprestasi ?

2. Bagaimana Efektivitas pelaksanaan peraturan perundang-undangan. yang terkait dengan Penegakan Hukum Kontrak

\section{PEMBAHASAN}

1. Bagaimana perlindungan hukum dan upaya hukum bagi penerima waralaba terhadap klausul-klausul kontrak waralaba yang tidak seimbang dan bertentangan dengan hukum persaingan usaha yang dapat ditempuh jika terjadi wanprestasi ?

Satjipto Raharjo mengatakan bahwa perlindungan hukum adalah memberikan pengayoman kepada hak asasi manusia yang dirugikan orang lain dan perlindungan tersebut diberikan kepada masyrakat agar mereka dapat menikmati semua hak-hak yang diberikan oleh hukum. ${ }^{3}$

Ada 4 unsur-unsur perlindungan hukum yaitu: ${ }^{13}$ 1) Adanya perlindungan dari pemerintah kepada warganya. 2) Jaminan kepastian hukum. Dalam undang-undang Richard B. Simatupang, Aspek Hukum Dalam Bisnis, cet. 2, Jakarta, PT. Rineka Cipta, 2003, hlm. 56 Thesis hukum.com, Pengertian Perlindungan Hukum Menurut Para Ahli, 13 April 2014 
dasar 1945 pasal 28 D ayat 1 menyebutkan bahwa setiap orang berhak atas pengakuan, jaminan, perlindungan dan kepastian hukum yang adil serta perlakuan yang sama didepan hukum. 5) Berkaitan dengan hak-hak kewarganegaraan. 6) Adanya sanksi hukuman bagi pihak yang melanggarnya.

Bisnis waralaba menjadi populer dan berkembang pesat di Indonesia karena bentuk ini menguntungkan kedua belah pihak yakni pemberi waralaba dan penerima waralaba. Bagi penerima waralaba keuntungan yang diperoleh yakni penerima waralaba tidak usah memulai bisnisnya dari nol karena bisnis pemberi waralaba (franchisor) sudah terkenal dan mempunyai pasar, sehingga penerima waralaba (franchisee) mempunyai peluang untuk berkembang cepat. Keuntungan menjalankan bisnis waralaba bagi pemberi waralaba adalah bisnisnya bisa berkembang lebih cepat di banyak lokasi secara bersamaan dan meningkatnya keuntungan dengan memanfaatkan investasi dari penerima waralaba. ${ }^{4}$

Pasal 1 angka 1 PP No. 42/2007 menyatakan bahwa waralaba harus didahului dengan adanya perjanjian. Apabila salah satu pihak melanggar perjanjian, maka pihak lain dapat menuntut pihak yang melanggar tersebut sesuai dengan hukum yang berlaku.

Perjanjian waralaba digolongkan sebagai perjanjian standar, karena isi dari perjanjian tersebut telah terstandarisasi isinya oleh pihak yang secara kedudukan ekonomi lebih kuat, sedangkan pihak lain yang secara ekonomi memiliki posisi tawar lebih rendah hanya dapat memutuskan apakah akan menerima atau menolak perjanjian tersebut tanpa memiliki kesempatan untuk melakukan perubahan terhadap isi dari perjanjian. Apabila menolak maka tentunya perjanjian itu dianggap tidak pernah ada karena debitur tidak menandatangani perjanjian tersebut.

Persoalan yang sangat mendasar dalam perjanjian baku ini adalah dalam mencantumkan hak dan kewajiban yang tidak seimbang, yakni selalu adanya pencantuman klausul eksonerasi (exculpatory clause) yaitu klausul yang menghilangkan tanggung jawab dari satu pihak ke pihak lain, contohnya, penjual yang tidak mau bertanggung jawab atas produk yang dijualnya mencantumkan klausul yang menyatakan bahwa barang yang sudah dibeli tidak dapat dikembalikan." maka, dari kasus yang terjadi telah ada pelanggaran perjanjian atau pemutusan perjanjian yang dilakukan oleh pihak yang membuat perjanjian baku dan dapat pula berupa suatu pelanggaran terhadap ketentuan undang-undang atau suatu perbuatan yang melanggar kepatutan dan kehati-hatian yang harus diperhatikan dalam hubungan antara masyarakat dan terhadap benda orang lain.

Perlindungan hukum yang dapat dilakukan kepada para pihak yakni subjek pelaku penerima waralaba (franchisee) dan pemberi waralaba (franchisor) yakni perlindungan hukum preventif dan represif. Perlindungan Hukum preventif bertujuan untuk mencegah terjadinya suatu sengketa yang dilakukan kedua belah pihak pelaku bisnis waralaba serta memberikan rambu- rambu atau batasan dalam melaksanakan kewajiban dalam waralaba. Sedangkan perlindungan hukum represif menitikberatkan pada mekanisme penyelesaian sengketa apabila terjadi permasalahan di kemudian hari.

Dalam hukum kontrak, penafsiran secara Iuas tentang Perbuaatan Melawan Hukum adalah perjanjian itu harus dibuat dengan itikad baik artinya dalam membuat perjanjian harus memperhatikan asas kepatutan, maka isi perjanjian yang berat sebelah tidak sesuai dengan kepatutan sehingga klasula tersebut dapat dinyatakan batal demi hukum dan tidak mengikat para pihak yang membuat perjanjian itu. ${ }^{5}$

\footnotetext{
Dewi Astuti, 2005, Kajian Bisnis Franchise Makanan di Indonesia, Jurnal Manajemen dan Kewirausahaan, Vol 7 No.1, hlm 91

5 Suharnoko, Hukum Perjanjian : Teori dan Analisa Kasus, cet. 3, Jakarta, Prenada Media, 2005, hlm 
Demikian pula halnya dengan ganti rugi atas wanprestasi tidak lagi berlaku mutlak walaupun masih relevan digunakan. Kerugian yang diakibatkan karena tidak tercapainya kesepakatan perjanjian waralaba bisa terjadi karena investasi awal yang mungkin telah dilaksanakan oleh calon franchisee berdasar pada janji-janji franchisor akan keuntungan besar yang dapat diraihnya. |Menurut teori klasik hukum kontrak, kerugian tersebut tidak dapat diklaim oleh pihak yang dirugikan karena kontrak belum terlaksana, oleh karenanya, tidak ada perjanjian. Dalam hal ini, bila hakim mengutamakan tujuan undang-undang untuk melindungi kepentingan pewaralaba (franchisee), ia tidak akan menemukan itikad baik dalam menentukan putusannya.

Perlindungan hukum bagi penerima waralaba terhadap klausul-klausul kontrak waralaba yang tidak seimbang dan bertentangan dengan hukum persaingan usaha dilaksanakan dalam tahap sebagai berikut:

Prosedur pertama yang wajib dipenuhi oleh para pihak dalam kontrak waralaba menurut PP No. 42/2007 adalah pendaftaran waralaba. Hal ini berguna untuk mencocokan dan menyesuaikan hal-hal yang disampaikan Pemberi Waralaba dalam prospektus penawaran waralaba (terutama mengenai hak dan kewajiban para pihak) dengan hal-hal yang diatur dalam kontrak waralaba.

Prosedur ini tidak dapat disimpangi begitu saja oleh para pihak dalam kontrak waralaba karena ada sanksi administratif berupa denda Rp. 100.000.000,- (seratus juta rupiah) yang dapat dibebankan kepada para pihak dalam kontrak waralaba yang menyimpangi prosedur tersebut.

Kontrak waralaba adalah kontrak lisensi HKI yang dilengkapi dengan sistem bisnis. Eksistensinya sebagai kontrak lisensi HKI mengakibatkan kontrak waralaba juga tunduk harus tunduk pada peraturan perundang-undangan di bidang HKI, khususnya mengenai pencatatan kontrak lisensi. Pencatatan kontrak waralaba sesuai dengan peraturan perundang-undangan di bidang HKI khususnya mengenai lisensi mengakibatkan kontrak waralaba tidak hanya mengikat para pihak dalam kontrak waralaba melainkan juga menimbulkan akibat hukum terhadap pihak ketiga.

Perlindungan hukum yang terakhir yang dapat dipergunakan oleh Penerima Waralaba dalam kontrak waralaba adalah gugatan pada Pengadilan yang berwenang. Gugatan yang diajukan oleh Penerima Waralaba melalui lembaga peradilan yang berwenang merupakan tahap perlindungan hukum yang terakhir dan terpenting bagi Penerima Waralaba untuk dapat memperoleh kedudukan yang seimbang dalam kontrak waralaba dan terlepas secara maksimal dari ancaman sanksi dalam UU No. 5/1999 tanpa perlu membatalkan kontrak waralaba tersebut.

\section{Bagaimana Efektivitas pelaksanaan peraturan perundang-undangan. yang terkait dengan Penegakan Hukum Kontrak}

Dalam setiap kegiatan usaha yang berjalan di Indonesia, baik itu antara pemilik (pengusaha) dengan karyawan maupun kemitraan (antar mitra) harus terdapat kontrak kerjasama yang jelas sehingga dapat melindungi kedua belah pihak apabila terjadi halhal yang tidak diinginkan dikemudian hari. Karena begitu pentingnya kontrak kerja dalam suatu hubungan kerja, khususnya hubungan dalam Usaha Waralaba anatara Franchisor (Pewaralaba) dan Franchisee (Penerima Waralaba).

Kewajiban pendaftaran dilakukan sebagai bentuk pengontrolan dari pemerintah namun di dalam Pasal 11 PP No. 42/2007 adanya kewajiban untuk mendaftarkan perjanjian oleh penerima waralaba, hal tersebut tidak relevan karena perjanjian merupakan hubungan keperdataan yang tidak melibatkan kepentingan publik, berbeda dengan kewajiban yang di atur dalam Pasal 10 tentang kewajiban pendaftaran 
Prospektus, karena propektus isinya mengenai informasi yang diterima publik dan negara wajib menvalidasi.

Selanjutnya di dalam Pasal 4 (1) adanya ketidakjelasan mengenai batasan tentang perjanjian waralaba harus berdasarkan hukum Indonesia, dengan begitu jika terjadi perjanjian yang tidak berdasarkan hukum Indonesisa dapat langusng dibatalkan atau seperti apa ?.

Berdasarkan Pasal 10 Peraturan Pemerintah Nomor 42 Tahun 2007 tentang Waralaba, pemberi waralaba juga wajib mendaftarkan prospektus penawaran waralaba sebelum membuat perjanjian Waralaba dengan Penerima waralaba. Pendaftaran prospektus penawaran waralaba bertujuan untuk mendapatkan Surat Tanda Pendaftaran Waralaba. Pemberi waralaba yang berasal dari dalam negeri wajib mendaftarkan prospektus penawaran waralaba ke Direktorat Bina Usaha Perdagangan up. Kantor Unit Pelayanan Perdagangan Kementerian Perdagangan dengan mengisi formulir surat permohonan Surat Tanda Pendaftaran Waralaba bagi pemberi waralaba dalam negeri.

Berdasarkan Pasal 4 ayat (1) Peraturan Menteri Perdagangan Nomor 53/MDAG/PER/8/2012 tentang Penyelenggaraan Waralaba pada saat pemberi waralaba melakukan penawaran kepada penerima waralaba, pemberi waralaba juga harus menyampaikan prospektus penawaran waralaba kepada penerima waralaba paling singkat 2 (dua) minggu sebelum penandatanganan perjanjian waralaba. Tujuan daripada penyampaian prospektus penawaran waralaba adalah agar penerima waralaba bisa melakukan studi kelayakan bisnis terhadap bisnis waralaba yang akan dijalaninya.

Prosedur pendaftaran waralaba tidak menentukan sahnya suatu kontrak waralaba karena produsen tersebut hanya diatur melalui PP No. 42/2007 bukan melalui UndangUndang. Sekalipun tidak menentukan syarat sahnya suatu perjanjian waralaba, prosedur mengenai pendaftaran waralaba tidak dapat dikesampingkan begitu saja. Dalam hal perjanjian waralaba dan prospektus penawaran waralaba tidak didaftarkan, maka terdapat sanksi yang dapat dijatuhkan sebagaimana dalam Pasal 16 ayat (1) Peraturan Pemerintah Nomor 42 Tahun 2007 tentang Waralaba. Sanksi yang diberikan dapat berupa sanksi administratif berupa peringatan tertulis dan sanksi administratif berupa denda.

KUH Perdata dengan jelas membedakan perikatan yang lahir dari perjanjian dengan perikatan yang lahir dari undang-undang (Pasal 1233 KUHPerdata). Akibat hukum yang lahir karena perjanjian memang dikehendaki oleh para pihak karena didasarkan atas kesepakatan mereka, sedangkan akibat hukum yang lahir karena undang-undang mungkin tidak dikehendaki oleh para pihak karena hubungan hukum dan akibat hukum ditentukan oleh undang-undang.

Saat ini banyak pelaku usaha yang tidak memahami karakteristik dari kontrak waralaba dan kaitannya dengan HKI. Mereka mengakui bahwa waralaba memang dilaksanakan berdasarkan sebuah kontrak waralaba, namun kontrak waralaba tersebut menurut mereka adalah suatu kontrak tersendiri yang dibuat dan disetujui para pihak hanya berdasarkan kebebasan berkontrak di antara para pihak saja. Pemikiran tersebut berimplikasi terhadap klausul-klausul di dalam kontrak waralaba yang cenderung tidak seimbang (berat sebelah) dan bertentangan dengan norma-norma hukum di bidang hukum persaingan usaha, khususnya UU No. 5/1999 Tentang Larangan Praktek Monopoli Dan Persaingan Usaha Tidak Sehat. Menurut Pasal 50 (b) UU No. 5/1999 tersebut, para pelaku usaha khususnya Pemberi Waralaba menganggap bahwa kontrak waralaba secara mutlak dikecualikan dari ketentuan tentang larangan-larangan dan sanksi yang dapat diterapkan sehubungan dengan pelanggaran terhadap laranganlarangan yang diatur di dalam UU No. 5/1999 tersebut. Hal ini lah kemudian dijadikan landasan oleh Pemberi Waralaba yang memiliki kedudukan lebih dominan dan kuat 
dengan sikap take it or leave it, untuk memaksakan kehendak secara tidak memadai kepada Penerima Waralaba.

Penerima Waralaba yang menyadari kelemahan posisinya tersebut, dengan terpaksa menyetujui klausul-klausul kontrak waralaba yang sebenarnya melanggar norma-norma hukum yang berlaku di bidang hukum kontrak bahkan bertentangan dengan UU No. 5/1999. Penerima Waralaba bahkan seringkali tidak diberikan kesempatan yang cukup untuk memeriksa kelengkapan legalitas dan melakukan studi kelayakan bisnis terhadap bisnis waralaba milik Pemberi Waralaba. Penerima Waralaba juga tidak pernah dilibatkan dalam hal Pemberi Waralaba bermaksud mengalihkan HKI yang diwaralabakan tersebut kepada pihak lain.

\section{PENUTUP}

\section{Kesimpulan}

a. Perlindungan hukum bagi penerima waralaba terhadap klausul-klausul kontrak waralaba yang tidak seimbang dan bertentangan dengan hukum persaingan usaha. Perlindungan hukum yang diberikan kepada penerima waralaba adalah berupa perjanjian waralaba yang dibuat oleh pemberi waralaba. Perlindungan hukum yang diberikan masih menguntungkan satu belah pihak yakni pemberi waralaba. Hal ini terlihat dari lebih banyaknya kewajiban atau tanggung jawab yang harus ditanggung dibandingkan dengan hak yang diperoleh pihak penerima waralaba.

b. Efektivitas pelaksanaan peraturan perundang-undangan. yang terkait dengan Penegakan Hukum Kontrak dalam hal Prosedur pendaftaran waralaba tidak menentukan sahnya suatu kontrak waralaba karena produsen tersebut hanya diatur melalui PP No. 42/2007 bukan melalui Undang-Undang. Sekalipun tidak menentukan syarat sahnya suatu perjanjian waralaba, prosedur mengenai pendaftaran waralaba tidak dapat dikesampingkan begitu saja. Dalam hal perjanjian waralaba dan prospektus penawaran waralaba tidak didaftarkan, maka terdapat sanksi yang dapat dijatuhkan sebagaimana dalam Pasal 16 ayat (1) Peraturan Pemerintah Nomor 42 Tahun 2007 tentang Waralaba. Sanksi yang diberikan dapat berupa sanksi administratif berupa peringatan tertulis dan sanksi administratif berupa denda.

\section{Saran}

a. Dalam usaha memberikan perlindungan hukum bagi penerimawaralaba, pemerintah hendaknya lebih memperketat pengawasan terhadap keberadaan para pemilik atau pemberi usaha waralaba terutama terhadap perjanjian waralaba yang dibuat.

b. Hendaknya pemilik usaha waralaba memberikan penjelasan dan pemahaman yang jelas kepada penerima waralaba mengenai kondisi usahanya yang mereka sedang jalankan dan memberikan perlindungan hukum yang jelas sehingga hal ini akan lebih baik bagi pihak penerima waralaba.

C. Untuk menghindari adanya sengketa atau perselisihan baik mengenaiperjanjian/kontrak maupun mengenai pelaksanaan isi perjanjian/kontrak Para pihak (franchisor dan franchisee) haruslah selalu beriktikad baik dalam menjalankan kesepakatan yang telah disepakati.

d. Sudah saatnya Waralaba ditingkatkan pengaturannya melalui suatu UndangUndang untuk menjamin terselenggaranya kepastian hukum dalam lalu lintas hukum, terlindunginya kepentingan masyarakat, dan terlindunginya pihak ketiga atau salah satu pihak dari tekanan pihak lain dalam kontrak waralaba dan perlu 
dilakukan revisi terhadap UU No. 5/1999 guna mengatasi beberapa kelemahan dalam penegakan hukum persaingan usaha di bidang waralaba

\section{DAFTAR PUSTAKA}

\section{Buku:}

Abdulkadir Muhammad, Hukum Perikatan, Citra Aditya Bakti, Bandung, 1990.

Arie Siswanto, Hukum Persaingan Usaha, Ghalia Indonesia, Jakarta, 2002.

A. Zen Umar Purba, "Pokok-pokok Pikiran Mengenai Pengaturan Persaingan Sehat Dalam Dunia Usaha”, Hukum dan Pembangunan.

Badrulzaman, Mariam Darus, Perkembangan Hukum Bisnis Menyongsong Era Globalisasi, Orasi Ilmiah pada Wisuda Sarjana Universitas Yarsi di Jakarta, 2 Nopember 1996.

Berman, Barry \& Evan, Sherman, Applying Retail Management, a Strategic Approach, Edisi II, Mac Millan, New York, 1999.

B.M. Kuntjoro Jakti, Materi Perkuliahan pada Program Pascasarjana Bidang Studi Ilmu Hukum Universitas Indonesia, 2 September 1997.

Fuady Munir, Hukum Bisnis dalam Teori dan Praktik, Citra Adtya Bhakti, Bandung, 1994.

Gunawan, Johannes, Product Liability dalam Hukum Bisnis Indonesia, Orasi Dies, Natalis XXXIX Universitas Katolik Parahyangan, Bandung, Januari, 1994.

H. Moch. Basarah \& H.M. Faiz Mufidin, Bisnis Franchise dan Aspek-Aspek Hukumnya, Citra Aditya Bakti, Bandung, 2008.

H.R. Daeng Naja, Pengantar Hukum Bisnis Indonesia, Pustaka Yustisia, Yogyakarta, 2009.

Joseph Mancuso \& Donald Boroian, Pedoman Membeli \& Mengelola Franchise, Delapratasa, Jakarta, 1995.

Lubis, Mulya. Hukum dan Ekonomi, Sinar Harapan, Jakarta, 1992.

, Undang-undang tentang Praktek Bisnis Tidak Sehat, Artikel Dimuat Suara Pembaharuan, 28 Nopember 1991.

Mochtar Kusumaatmadja, Konsep-konsep Hukum dan Pembangunan, Alumni.- Bandung, 2002.

Munir Fuadi, Hukum Bisnis Dalam Teori dan Praktek, Citra Aditya Bhakti, Bandung, 1994.

Partnership for Business Competition, Pengantar Menuju Pelaksanaan Persaingan Usaha, Position Paper, Hotel Gran Melia, Jakarta, 25 Januari 2000.

Purwadi, S. Meningkatkan Profit dengan Cara Mengatasi Kehilangan Barang, Artikel di www.smfranchise.com, Januari 2003.

R. Subekti, Hukum Perjanjian, Intermasa, Jakarta, 1987.

Shauki, Ahmad, 1998, Kebijakan Persaiangan Sehat Guna Menciptakan Perekonomian Yang Efisien, Makalah, disampaikan dalam Diskusi Cinles-Elsam.

Suhartono, R.B. Konglomerasi dan Relevansi Undang-undang Antitrust/Undang-undang Antimonopoli, dalam Jurnal Hukum Bisnis Volume 4, 1998.

Suwito, Santoso \& A. Sanda, Trend Bisnis Baru, Trade Center, Artikel, Kompas, 19 Nopember 2002 Properti.

\section{Perundang-undangan:}

Indonesia, Undang Undang Dasar 1945

Undang Undang Nomor 9 Tahun 1995 tentang Usaha Kecil.

Peraturan Pemerintah No. 42 Tahun 2007 tentang Waralaba. 